relationships with their new friends and many have requested second and third families.

\section{FRIENDSHIP FAMILIES IN TORONTO}

\section{by Roni Chaleff, Operation Lifeline}

Finding housing, employment and language classes, let alone friends, is not easy for newcomers no matter where they are. When mass transit enters the picture; when one needs to be able to read the newspaper to locate jobs and housing, call quickly, and get there before someone else gets there first; when there is no community centre and sometimes not even an easily-defined community; the situation grows impossible. In a sprawling urban environment, it is crucial to know there is someone you can turn to when you need help and the Manpower office is closed. It is crucial to know there is someone who cares.

Any person, family or group who is interested in becoming a Friendship Family to provide this orientation assistance and social contact to a government-sponsored refugee on an ongoing basis, first attends one of our monthly orientation meetings. Then he submits an information sheet about himself, and the process begins of matching him with one refugee or refugee family newly arrived in the city, either from overseas or often from elsewhere in the country.

\section{NDS, FRIENDS . . .}

$\begin{array}{ll}\text { nployment and } & \text { Emploiet } \\ \text { רmigration Canada } & \text { Immigration Canada }\end{array}$

. and Mrs. Mai:

forgive me for writing in English. I wish that I could write in your own language, but Quyen assured me that you would be , read English.

allow me to introduce myself. Quyen came to Canada under the ship of the Canadian government, and I am the government representasponsible for the wellbeing of the vietnamese immigrants in

ville area, which is where Quyen was sent. It is my responsibility

that they are enrolled in English-language classes as soon as

e, that they have a suitable place to live, enough clothes and

ind to help them find employment when they have learned English.

have done for Quyen: he is now settled in a very pleasant apart

th two other young men from Saigon, and they are all studying

Ird, and doing very well in their English classes.

:d to write this letter to you for several reasons: first, because

mother myself--my husband and I have five children, some of

ound the same age as Quyen, and therefore I know how difficult

ber son so far away in a strange

', and how concerned you must be for his welfare.

ie than that, my husband and I have become very fond of Quyen ifriends. They have been to our house many times for dinner the evening, and we have come to feel almost as if they were sorry that their lives have been interrupted by tragedy. However, is a good country with many opportunities for young people is a good country, with many oppilum iey need to build their lives again.

is obviously a very intelligent young man--he is one of the best is in his English class--and when he is at our house we enjoy is in his English class-and when he is at our house we enjoy pas his family. He has show us pictures of his brother and and - well. However. please do not worry about his welfare--we will ire that he is taken care of.

would like to write to me, I would be happy to answer any questions tht have.

:ly,

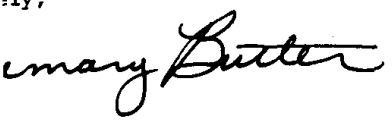

In such a large city we find it necessary to screen volunteers before actually introducing them to the refugees. A volunteer social worker does this by phone.

The Friendship Family and the refugees are first introduced by an interpreter. Later, since the Friendship Families come from all walks of life and from all parts of the city and would never have a chance to meet, organized meetings offer them an important opportunity to share their stories, their experiences in coping with difficulties, their discoveries of fun and cheap activities. Meetings for the newcomers in their own languages help clear up any concerns they have about their Friendship Families or any questions about employment, language classes, getting their families out of the refugee camps, etc. Finally, parties and cultural events contribute to a sense of community spirit on both sides, which is usually so difficult to create in a large city.

The Friendship Families themselves do much of the administration of the programme, including general office work, organizing social activities, speaking to their church groups to recruit more volunteers, and giving interviews to the media to publicize the programme. But one full-time coordinator is also necessary, as well as contract workers who speak Vietnamese, Chinese, Lao and Khmer.

\section{WINNIPEG'S ESCORT SERVICE}

\section{by Marjery Soloman, Manitoba Joint Refugee Coordinating Committee}

The "Be A Friend" programme of the Manitoba Joint Refugee Coordinating Committee was initiated in response to concerns expressed by the community for the government-sponsored Southeast Asian refugees arriving in Winnipeg.

We asked volunteers to work for one half day a week escorting people to medical appointments, helping to enroll children in school, explaining public transit or helping a family with their shopping. Soon many of the volunteers were recruiting their spouses, teen-age children and friends to help, and increasing their own volunteer time.

A former home economics teacher spends three afternoons a week explaining the complexities of shopping in a North American supermarket and showing families where they can find the oriental groceries necessary for their cooking. A retired businessman spends many hours preparing resumes and helping to find employment. New mothers are visited in hospital by a volunteer who not only makes sure that they will be able to manage on their own when they go home but supplies them with whatever baby clothes and equipment they may need from a seemingly endless supply she gathers from friends and acquaintances. Expectant mothers want to be assured that "Mrs. Mary" will come to see them after their babies are born.

Volunteers help people through the maze of government and agency offices - they act as advocates they help to locate more suitable housing - they drive people to the hospital regardless of the hour - they take families on friendly outings - they seldom say "no."

We are pleased that our seventy plus Canadian volunteers are now being joined by many volunteers from the refugee community. These people are now ready to "be a friend" and help someone else start a new life in Canada. 